\title{
Mind Map Value Proposition Design
}

Evelyn Patricia Haryono, 2440006431, Universitas Bina Nusantara, evelyn.haryono@binus.ac.id Content: Canvas, Design, Test, Evolve

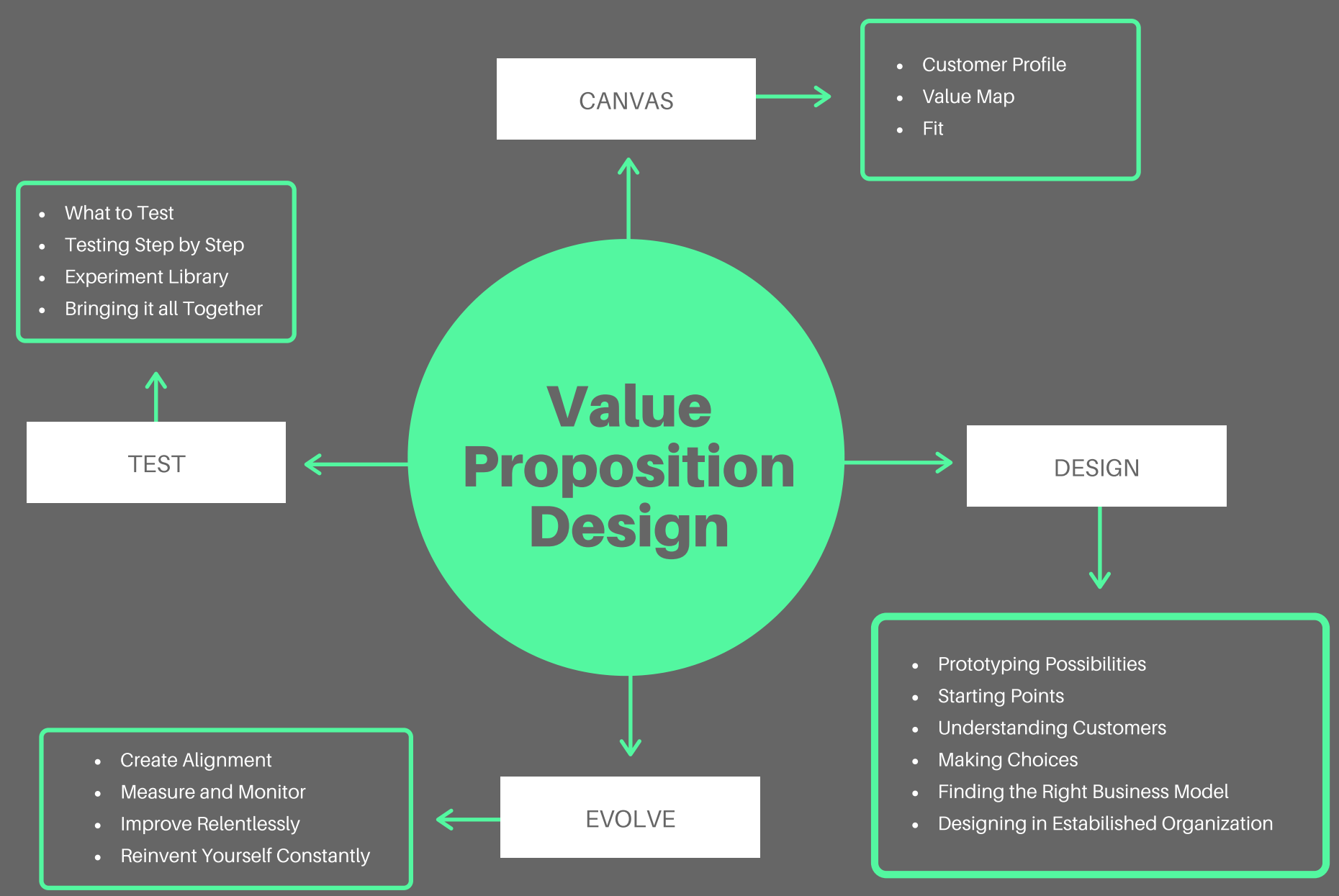

Reference: Alexander Osterwalder, Yves Pigneur, Greg Bernarda \& Alan Smith (2014) Value Proposition Design, John Wiley \& Sons, Inc. Dosen Pembimbing: Agung Purnomo 